\title{
Effect of Cultivation Methods on Wood Static Bending Properties in Alnus Glutinosa
}

\section{Utjecaj načina uzgoja crne johe na njezina statička savojna svojstva}

\author{
Original scientific paper • Izvorni znanstveni rad \\ Received-prispjelo: 12. 8. 2012. \\ Accepted-prihvaćeno: 6. 11. 2013. \\ UDK: $630 * 2 ; 630 * 812.71 ; 674.031 .22$ \\ doi:10.5552/drind.2013.1240
}

\begin{abstract}
This study was carried out to determine radial variation of wood density, modulus of elasticity (MOE), modulus of rupture (MOR) and stress at elastic limit in plantation and natural alder (Alnus glutinosa) forests in north of Iran. Testing samples were taken at breast height of the stem and at three radial positions (10, 50 and $90 \%$ of radius) for both cultivation methods (natural and plantation forests) to determine wood mechanical strength properties according to the ASTM standard. Analysis of variance indicated that cultivation methods (natural and plantation forest), radial position and interaction between planting position and radial direction had no significant effects on the modulus of elasticity (MOE), modulus of rupture (MOR) and stress at elastic limit in alder wood. Only the radial position had a significant effect on the wood density. Wood density was increased along radial direction from the pith to the periphery for both planting conditions. Overall, the mechanical strength properties in plantation forest were slightly higher than in natural forest. The relationship between wood density and mechanical properties were analyzed by linear regression. A positive relationship was found between wood density and mechanical properties for both planting conditions. These relationships were stronger in plantation forest than in natural forest.
\end{abstract}

Keywords: Alnus glutinosa, modulus of elasticity, modulus of rupture, Fiber stress at elastic limit, cultivation methods (natural and plantation forest)

SAŽETAK • Istraživanje je provedeno kako bi se u radijalnome smjeru utvrdile varijacije gustoće drva, modula elastičnosti (MOE), modula loma pri savijanju (MOR) i naprezanja na granici elastičnosti drva crne johe (Alnus glutinosa) iz plantažne i prirodne šume johe sa sjevera Irana. Ispitni uzorci uzeti su na prsnoj visini stabala s tri radijalne pozicije (10, 50 i 90 \% radijusa) iz oba načina uzgoja (iz prirodne i plantažne šume) kako bi se utvrdila mehanička svojstava drva prema standardu ASTM. Analiza varijance pokazala je da način uzgoja crne johe (prirodna i plantažna šuma), radijalni položaj, kao i interakcija između položaja samog stabla i položaja uzorka u radijalnome smjeru nisu imali statistički značajnog utjecaja na modul elastičnosti, modul loma pri savijanju, kao ni na naprezanje na granici elastičnosti. Radijalni položaj uzoraka imao je značajnog utjecaja samo na gustoću drva. Gustoća drva povećavala se u radijalnom smjeru od srčike prema kori, bez obzira na način uzgoja šuma. Općenito, ispitivana mehanička svojstva drva crne johe iz plantažne šume bila su nešto bolja od mehaničkih svojstava drva iz prirodne šume. Odnos između gustoće drva i ispitivanih mehaničkih svojstava analiziran je linearnom regresijom. Utvrđen je pozitivan odnos između gustoće drva i ispitivanih mehaničkih svojstava za oba

\footnotetext{
${ }^{1}$ Author is professor at Department of Wood and Paper Engineering, Chaloos Branch, Islamic Azad University, Chaloos, Iran.

${ }^{1}$ Autor je profesor Odjela za tehnologiju drva i papira, Islamsko sveučilište, Chaloos, Iran.
} 
načina uzgoja šuma. Ti odnosi između gustoće drva i ispitivanih mehaničkih svojstava jače se očituju u drvu johe iz plantažnog uzgoja nego iz prirodnog uzgoja.

Ključne riječi: Alnus glutinosa, modul elastičnosti, modul loma pri savijanju, naprezanje na granici elastičnosti, prirodna i plantažna šuma

\section{INTRODUCTION}

\section{UVOD}

The Alnus glutinosa is diffuse-porous hardwood species from Betulaceae family, which accounts for about 9 percent of the growing stock in Northern forests according to the Iranian forest organization. Alder wood is soft or semi-hard, and light density (moisture content of $15 \%$ ) hardwood $\left(0.4-0.67 \mathrm{~g} / \mathrm{cm}^{3}\right)$. In our forests, there are two species of this fast growing wood: Alnus subcordata and Alnus glutinosa. These species have good nailing ability, good adhesiveness, they are highly colorable and have low durability. They are mostly used for box-making, water structures, boatmaking, furniture, plywood and veneer (Parsapajouh, 1998).

Wood quality can be measured directly by submitting timber to a large number of technical tests. However, many of wood traits such as strength and elasticity properties are related to density. This parameter is suitable for predicting wood quality (Panshin and De Zeeuw, 1980). For a specific species, the wood density is very variable among trees due to genetic and environmental differences (Zahner, 1968). The relation between density and site index depends on difference in growth rate, which is a very complex issue (Taylor and Wooten, 1937). Wood density varied along longitudinal and radial directions from bottom to the up and from pith to bark (Zhang and Zhong, 1990). Variations of wood density may be directly related to variation in cell wall percentages and changes in cell wall thickness, cell diameter and tissue proportions (Zahner, 1968).

A research on the comparison of wood properties of planted big-leaf mahogany in Martinique Island with naturally grown Mahogany from Brazil, Mexico and Peru (there are two age groups such as young trees $[<40$ years old] and old trees [ $>40$ years old] for plantation trees) indicated that wood density of plantation trees (young and old trees) was lower than that of natural forest trees. Although the density of natural forest wood was higher than that of plantation trees, the difference in modulus of elasticity (MOE) was not significant. The static bending strength (MOR) of young and old trees was significantly lower than that of natural forest trees (Langbour et al., 2011). The mean values of dried density, basic density, volumetric shrinkage, volumetric swelling, fiber saturation point, modulus of elasticity and modulus of rupture for Turkish alder wood (Alnus glutinosa) were respectively determined as $0.454 \mathrm{~g} / \mathrm{cm}^{3}, 0.399 \mathrm{~g} / \mathrm{cm}^{3}, 12.62 \%, 13.78$ \%, $32.87 \%$, 8.61 GPa and 77.53 MPa (Korkut and Guller, 2008).
There were no information about mechanical strength properties and other characteristics and differences between plantation-natural forests for Alnus glutinosa species in Iran. Therefore, the aims of this study of Alnus glutinosa were: a) to examine wood density, modulus of elasticity, modulus of rupture and stress at elastic limit along radial direction from pith to bark for both planting conditions (natural and plantation forest), and b) to investigate the relationship between wood density and static bending strength for both cultivation methods (a species grown in two different ways).

\section{MATERIAL AND METHODS}

\section{MATERIJALI I METODE}

\subsection{Materials}

2.1. Materijali

Study material comes from six alder trees (Alnus glutinosa) sampled from two planting conditions in the eastern part of Mazandaran province (Savadkouh region) in the north of Iran. These planting conditions were plantation and natural forests. Logs and discs were cut at breast height for each tree. Selected trees with straight trunks, normal branching and no disease or pest symptoms were felled. From each selected tree, a log $50 \mathrm{~cm}$ long was extracted at breast height diameter $(d b h)$. The plantation alder trees were 20 years of age and natural forest trees 20-22. The mean values of annual ring width in the plantation alder trees and natural alder forest were 6.95 and $6.86 \mathrm{~mm}$, respectively. In this region, the average air temperature was $11.2{ }^{\circ} \mathrm{C}$ and the sum of annual rainfall was $386 \mathrm{~mm} / \mathrm{year}$. The altitude was $120 \mathrm{~m}$ for plantation forest and $350 \mathrm{~m}$ for natural forest. The soil of this region is similar for both planting conditions.

\subsection{Methods}

2.2. Metode

\subsubsection{Static bending properties}

2.2.1. Svojstva pri statičkom ispitivanju na savijanje

Wood samples for testing were taken along the radial direction from pith to bark (three positions from pith $10,50,90 \%$ of radius) in four geographical directions of trees to determine static bending properties according to the ASTM-D143-94 standards. The dimensions of samples were $25 \times 25 \mathrm{~mm}$ in cross section and $410 \mathrm{~mm}$ in longitudinal direction. The length span of $360 \mathrm{~mm}$ was required to determine the modulus of elasticity $(M O E)$, modulus of rupture (MOR) and stress at elastic limit. The prepared samples were then conditioned at the temperature of $20 \pm 2{ }^{\circ} \mathrm{C}$ and at $65 \pm 5 \%$ 
relative humidity until the specimens reached an equilibrium moisture content of about $12 \%$. Three different static bending strength parameters, fiber stress at elastic limit ( $F S$ at $L P$ in $\mathrm{MPa}$ ), modulus of rupture $(M O R$ in $\mathrm{MPa}$ ) and modulus of elasticity ( $M O E$ in $\mathrm{MPa}$ ) were computed using the equations (1), (2) and (3):

$$
\begin{aligned}
& F S \text { at } L P=3 \cdot P \cdot l / 2 \cdot b \cdot h^{2} \\
& M O R=3 \cdot P_{\max } \cdot l / 2 \cdot b \cdot h^{2} \\
& M O E=P \cdot l^{3} / 4 \cdot D \cdot b \cdot h^{3}
\end{aligned}
$$

Where

$P$ - load at the limit of proportionality, kN,

$P_{\text {max }}$ - maximum load, $\mathrm{kN}$,

$l$ - span of the test specimen, $\mathrm{mm}$,

$b$ - breadth of the test specimen, $\mathrm{mm}$,

$h$ - depth of the test specimen, mm,

$D$-deflection at the limit of proportionality, $\mathrm{mm}$.

Finally, the specimens were examined to determine wood oven-dry density based on the ISO-3131 standard $(20 \times 20 \times 20 \mathrm{~mm})$. The samples were ovendried at $103 \pm 2{ }^{\circ} \mathrm{C}$ to $0 \%$ moisture content. After cooling in desiccators, the oven-dry weights of the specimens were measured. The values of the wood oven-dry density were calculated using the following equation (4):

$$
\rho_{0}=\frac{m_{0}}{V_{0}}
$$

Where

$\rho_{0}$ - density in absolutely dry condition,

$m_{0}$ - weight in absolutely dry condition,

$V_{0}$ - volume in absolutely dry condition.

\subsubsection{Statistical analysis}

\subsubsection{Statistička analiza}

To determine the effect of cultivation methods (natural and plantation trees) and radial direction on the static bending properties and wood density, statistical analysis was conducted using the SPSS programming method in conjunction with the analysis of variance (ANOVA) techniques. A linear regression model was used to analyze the relationship among the various properties for both cultivation methods in alder wood.

\section{RESULTS OF RESEARCH \\ 3. REZULTATI ISTRAŽIVANJA}

\subsection{Wood density}

3.1. Gustoća drva

Radial variation of wood density for plantation forest and natural forest are shown in Table 1. Analysis of variance (ANOVA) indicated that the effects of cultivation methods $(F=0.169$, sig $=0.685)$, and their interaction between cultivation methods and radial position $(F=4.253$, sig $=0.026, P<0.05)$ had no significant effect on wood density. There are, however, significant differences in wood density among radial samples ( $F=$ 0.488 , sig $=0.620$ ). The average wood density in plantation forest was slightly higher than that in natural alder forest. Wood density increased in the radial direction from pith to bark for both planting conditions. The average wood density in plantation and natural alder trees was 0.396 and $0.391 \mathrm{~g} / \mathrm{cm}^{3}$, respectively.

\subsection{Modulus of elasticity (MOE) \\ 3.2. Modul elastičnosti (MOE)}

Radial variation of modulus of elasticity (MOE) for plantation forest and natural forest are shown in Table 2. Analysis of variance (ANOVA) indicated that the effects of cultivation methods $(F=0.911$, sig $=0.349)$, radial position $(2.528$, sig $=0.101)$ and their interaction

Table 1 Mean values (coefficients of variation) of wood density in plantation and natural alder forests

Tablica 1. Srednje vrijednosti i koeficijenti varijacije $(\mathrm{CV}, \%)$ gustoće drva crne johe iz plantažne i prirodne šume

\begin{tabular}{|l|c|c|}
\hline $\begin{array}{l}\text { Radial direction } \\
\text { Pozicija u radijalnome smjeru }\end{array}$ & $\begin{array}{c}\text { Natural forest } \\
\text { Prirodna šuma }\end{array}$ & $\begin{array}{c}\text { Plantation } \\
\text { Plantažna šuma }\end{array}$ \\
\hline Pith / srčika & $0.37(3.24)$ & $0.388(5.67)$ \\
\hline Middle / sredina & $0.392(8.16)$ & $0.385(6.75)$ \\
\hline Bark / kora & $0.412(8.49)$ & $0.414(6.03)$ \\
\hline Mean / aritmetička sredina & 0.391 & 0.396 \\
\hline
\end{tabular}

Table 2 Mean values (coefficients of variation) of modulus of elasticity (MOE) in plantation and natural alder forests

Tablica 2. Srednje vrijednosti i koeficijenti varijacije modula elastičnosti $(M O E)$ drva crne johe iz plantažne i prirodne šume

\begin{tabular}{|l|c|c|}
\hline $\begin{array}{l}\text { Radial direction } \\
\text { Pozicija u radijalnome smjeru }\end{array}$ & $\begin{array}{l}\text { Natural forest } \\
\text { Prirodna šuma }\end{array}$ & $\begin{array}{c}\text { Plantation } \\
\text { Plantažna šuma }\end{array}$ \\
\hline Pith / srčika & $5.85(19.14)$ & $6.59(10.68)$ \\
\hline Middle / sredina & $5.88(6.75)$ & $6.24(5.83)$ \\
\hline Bark / kora & $7.04(6.87)$ & $7.04(11.57)$ \\
\hline Mean / aritmetička sredina & 6.25 & 6.62 \\
\hline
\end{tabular}


Table 3 Mean values (coefficients of variation) of modulus of rupture (MOR) in plantation and natural alder forests Tablica 3. Srednje vrijednosti i koeficijenti varijacije (CV, \%) modula loma pri savijanju drva crne johe iz plantažne i prirodne šume

\begin{tabular}{|l|c|c|}
\hline $\begin{array}{l}\text { Radial direction } \\
\text { Pozicija } \text { u radijalnome smjeru }\end{array}$ & $\begin{array}{l}\text { Natural forest } \\
\text { Prirodna šuma }\end{array}$ & $\begin{array}{c}\text { Plantation } \\
\text { Plantažna šuma }\end{array}$ \\
\hline Pith / srčika & $42.27(12.56)$ & $44.34(12.49)$ \\
\hline Middle / sredina & $45.61(11.90)$ & $47.57(7.60)$ \\
\hline Bark / kora & $46.61(19.05)$ & $53.29(17.35)$ \\
\hline Mean / aritmetička sredina & 44.83 & 48.4 \\
\hline
\end{tabular}

Table 4 Mean values (coefficients of variation) of fiber stress at elastic limit in the plantation and natural alder forests Tablica 4. Srednje vrijednosti i koeficijenti varijacije (CV, \%) naprezanja na granici elastičnosti drva crne johe iz plantažne i prirodne šume

\begin{tabular}{|l|c|c|}
\hline $\begin{array}{l}\text { Radial direction } \\
\text { Pozicija } \text { u radijalnome smjeru }\end{array}$ & $\begin{array}{l}\text { Natural forest } \\
\text { Prirodna šuma }\end{array}$ & $\begin{array}{c}\text { Plantation } \\
\text { Plantažna šuma }\end{array}$ \\
\hline Pith / srčika & $16.91(12.65)$ & $17.73(12.46)$ \\
\hline Middle / sredina & $18.25(11.89)$ & $19.02(7.62)$ \\
\hline Bark / kora & $17.64(21.48)$ & $21.31(17.31)$ \\
\hline Mean / aritmetička sredina & 17.60 & 19.35 \\
\hline
\end{tabular}

$(F=0.343$, sig $=0.713)$ had no significant effect on $M O E$. The average $M O E$ in plantation forest (6.62 $\mathrm{GPa})$ was slightly higher than that in natural alder forest (6.25 GPa). The average $M O E$ varied from pith to bark from 5 to $7 \mathrm{GPa}$ for natural alder stems and varied from 6 to $7 \mathrm{GPa}$ for plantation alder stems.

\subsection{Modulus of rupture (MOR)}

3.3. Modul loma pri savijanju drva (MOR)

Radial variation of modulus of rupture $(M O R)$ for plantation forest and natural forest are shown in Table 3. Analysis of variance (ANOVA) indicated that the effects of cultivation methods $(F=1.974$, sig $=0.173)$, radial position $(F=2.511$, sig $=0.102)$ and their interaction $(F=0.388, \mathrm{sig}=0.683)$ had no significant effect on $M O R$. The average $M O R$ in plantation forest (48.40 $\mathrm{MPa}$ ) was slightly higher than that in natural alder forest (44.83 MPa). With natural alder stems, the increment of $M O R$ from pith to bark was, on average, 42 to $47 \mathrm{MPa}$, and with plantation alder stems from 44 to 54 $\mathrm{MPa}$.

\subsection{Fiber stress at elastic limit}

3.4. Naprezanje vlakanaca na granici elastičnosti

Radial variation of fiber stress at elastic limit for plantation forest and natural forest are shown in Table 4. Analysis of variance (ANOVA) indicated that the effects of cultivation methods $(F=2.854$, sig $=0.104)$, radial position $(F=1.614$, sig $=0.220)$ and their interaction $(F=0.879$, sig $=0.428)$ weren't significant on the fiber stress at elastic limit. The fiber stress at elastic limit averaged 16.91 $\mathrm{MPa}$ in the pith part, 18.25 MPa in middle part, and 17.64 MPa in bark part, for natural alder stems. This factor was respectively determined 17.73, 19.02 and 21.31 MPa for plantation alder stems.

\subsection{Relationship between wood density and various wood properties}

3.5. Odnos između gustoće drva i ispitivanih mehaničkih svojstava

The dependence of static bending properties (modulus of elasticity, modulus of rupture and fiber stress at elastic limit) on the oven-dry density was modeled using simple regression equations (Figure 1). The correlation coefficient between wood density and $M O E, M O R$, and stress at elastic limit in plantation alder wood ( $R^{2}=0.613,0.488$ and 0.302 , respectively) was higher compared to natural alder wood $\left(R^{2}=0.505\right.$, 0.296 and 0.042 , respectively). Furthermore, the correlation coefficient between wood density and $M O E$ was considerably higher than the relationship between wood density-MOR and wood density-fiber stress at elastic limit. Overall, positive relationships were found between wood density and different static bending strength properties of wood for both planting conditions. 

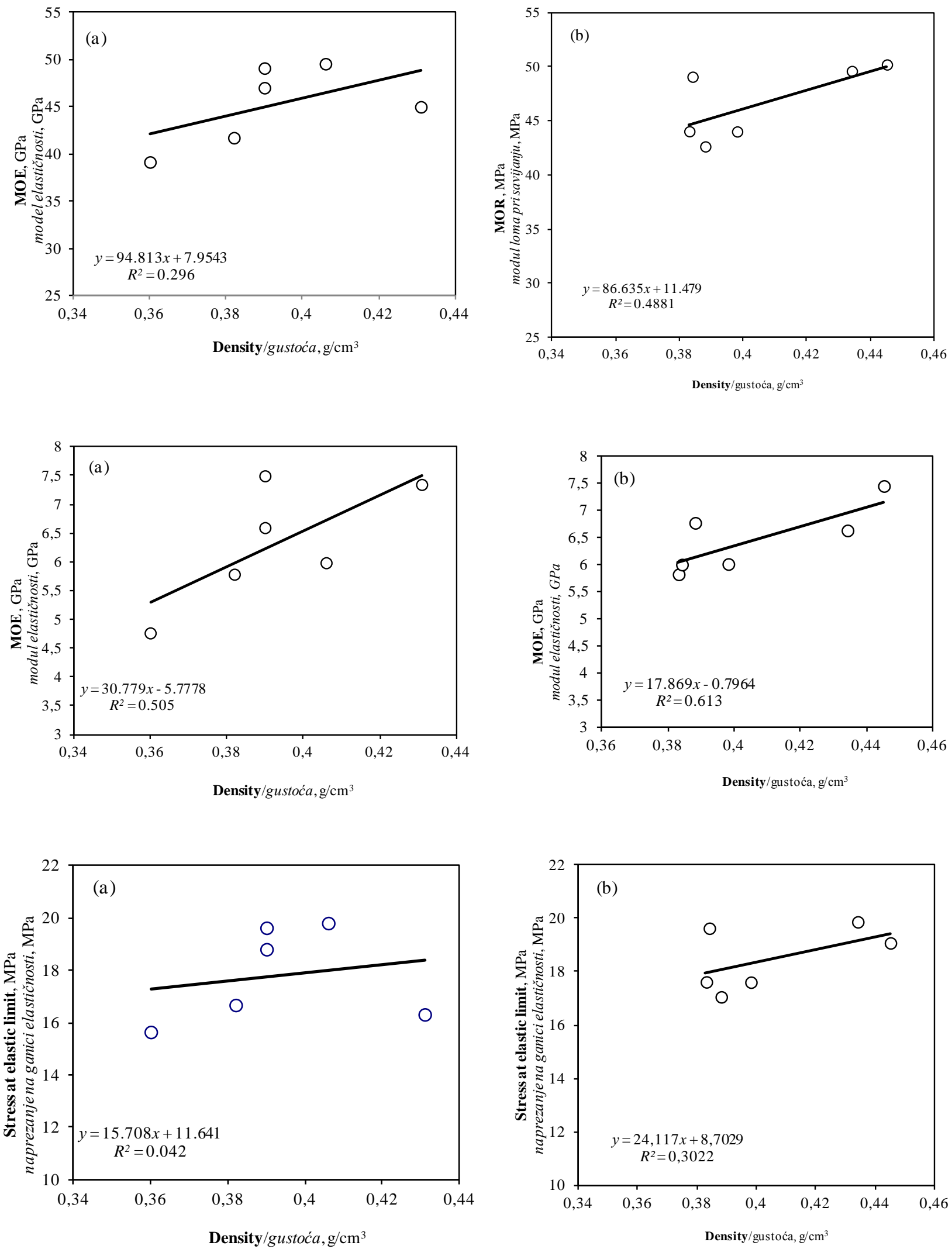

Figure 1 Relationship between wood mechanical properties and density of alder wood: a) from natural forest; b) from plantation

Slika 1. Međusobni odnos testiranih mehaničkih svojstava i gustoće drva johe: a) iz prirodne šume; b) iz plantažne šume 


\section{DISCUSSION}

\section{RASPRAVA}

Many researchers suggest that trees growing in plantations produce wood of the lowest properties, such as wood density and other wood variables (Zobel and Sprague, 1998). For example, Terminalia amazonia trees from natural forests in Panama (Llach, 1971), Nicaragua (González, 1973), Bolivia, Venezuela and Colombia (Keenan and Tejada, 1987), and Honduras (Shupe et al., 2005), among others, were reported to have superior mechanical properties to those from the forest plantations evaluated by Moya and Munoz (2010) study. Furthermore, Swietenia macrophylia trees from natural forests had better mechanical strength properties than plantation mahogany trees (Langbour et al. 2011). Alnus glutinosa tress from natural forests in Turkey (Korkut and Guller, 2008; Guller and Ay, 2001) were reported to have superior mechanical strength properties to those from the forest plantations and natural forests evaluated in the present study. The wood density of Turkish natural alder wood $(0.454$ $\left.\mathrm{g} / \mathrm{cm}^{3}\right)$ was higher than that of Iranian natural $(0.391 \mathrm{~g} /$ $\left.\mathrm{cm}^{3}\right)$ and plantation $\left(0.396 \mathrm{~g} / \mathrm{cm}^{3}\right)$ alder forests. These values were found for modulus of rupture and modulus of elasticity of alderwood in Turkey and in the present study. The mentioned properties were $77.53 \mathrm{MPa}$ and 8.61 GPa for Turkish alder stems (Korkut and Guller, 2008; Guller and Ay, 2001). In addition, the wood mechanical properties of Iranian Alnus glutinosa are lower than those of Alnus acuminata in Costa Rica country (Moya and Munoz, 2010). These divergent results suggest a probable influence of site and environmental condition on wood quality. Zobel and Van Buijtenen (1989) suggest that large structure variations are produced by changes in climate, site and management characteristics, as a product of these extrinsic factors influencing various activities. Our study indicated that there are no significant differences between natural and plantation forests in the wood density and static bending properties. The wood density, modulus of rupture, modulus of elasticity and stress at elastic limit were slightly higher in plantation alder wood than in natural alder wood.

Some researchers have reported that different properties of wood increase with age or distance from the pith (in diffuse porous species). This is supported by the fact that juvenile wood is usually known to be of a lower density than mature wood (Zobel and Van Buijtenen, 1989; Heräjärvi, 2004; Hrázský and Král, 2010; Kord et al., 2010). Our study indicated that the radial direction had no significant effect on the static bending of natural and plantation alder stems. This phenomenon can be related to the fact that the transition stage of juvenile wood to mature wood did not happen in natural and plantation alder trees due to their low age.

A positive correlation between wood density and static bending (MOE, MOR and stress at elastic limit) was found in both planting conditions. Similar trend has also been reported by several researchers for different hardwood and softwood species (Zhang, 1997; Bet- kas et al., 2002; Heräjärvi, 2004). The values of correlation coefficients between wood density and different mechanical strength properties were higher in plantation forest than in natural alder forest.

\section{CONCLUSIONS 5. ZAKLJUČCl}

The present research determined the static bending properties of natural and plantation alder stems in the Savadkouh - Mazandaran region. The following conclusions were obtained from this study:

1. There are no significant differences between cultivation methods (natural and plantation alder stem) in wood density, MOE, MOR and stress at elastic limit.

2. Radial variation of wood strength indicated that the MOE, MOR and stress at elastic limit increased with increasing cambial age in both planting conditions, and that these differences were not significant. The effect of radial variation on the wood density was significant.

3. The interaction between radial direction and cultivation methods had no significant effect on the wood density, MOE, MOR, and fiber stress at elastic limit

4. Positive relationship between wood density and mechanical properties was found in natural and plantation alder stems. According to correlation coefficients, these relationships are stronger in plantation alder forest than in natural alder forest.

5. Wood density is an important parameter of wood quality. Wood quality of plantation forest is similar to the quality of natural forest when referring to alder wood. So plantation alder wood may be used in the same way as natural alder wood in different wood industries.

\section{REFERENCES}

\section{LITERATURA}

1. American Society for Testing and Materials (ASTM) 2003b: Test Methods for Small Clear Specimens of Timber. ASTM D 143-94. Reproved 2000. Volume 04-10. ASTM, Philadelphia.

2. Bektas, I.; Guler, C.; Basturk, M. A., 2002: Principal mechanical properties of eastern beech wood (Fagus orientalis) naturally grown in Andirin northeastern Mediterranean region of Turkey. Turkish Agriculture and Forestry 26: 147-154.

3. González, G.; Wiessel, C.; Chavarri, G., 1973: Propiedades y Usos de Quince Especies Maderables del Nordeste de Nicaragua. FO: SF/NIC 9. Informe Técnico 9. Gobierno de Nicaragua, Managua.

4. Guller, B.; Ay, N., 2001: Some mechanical properties of alder [Alnus glutinosa subsp. barbata (C.A. Mey.) Yalt.] wood obtained from Artvin region. Tubitak Turkish Journal of Agriculture and Forestry 25, 129-138.

5. Hrázský, J.; Král, P., 2010: Analysis of Selected Mechanical Properties of Construction Wood KVH and Parallam 2.0 E. Drvna Industrija 61(1): 15-26. 
6. Herajarvi, H., 2004: Static bending properties of Finnish birch wood. Wood Science and Technology 37:523-530, DOI 10.1007/s00226-003-0209-1

7. Keenan, F. J.; Tejada, M., 1987: Maderas Tropicales Como Material de Construcción en los Países del Grupo Andino de América del Sur. Centro Internacional de Investigaciones para el Desarrollo, Ottawa.

8. Kord, B.; Kialashkai, A.; Kord, B., 2010: The within-tree variation in wood density and shrinkage, and their relationship in Populus euramericana. Turkish Agriculture and Forestry 34: 121-126. http://dx.doi.org/10.3906/tar0903-14.

9. Korkut, S.; Guller, B., 2008: Physical and mechanical properties of European Hophornbeam (Ostrya carpinifolia Scop.) wood. Bioresour Tech. 99: 4780-4785.

10. Langboar, R.; Gerard, G.; Roda, G. M.; Fauzi, P. A.; Guibal, D., 2011: Comparison of wood properties of planted big-leaf mahogany (Switetenia macrophglla) in Martinia Island with naturally grown mahogangy from Barazil, Mexico, and Peru. Journal of Tropical Forest Science 23(3): 252-259.

11. Llach, L., 1971: Propiedades físicas y mecánicas de ciento trece especies maderables de Panamá. Parte 3. Universidad de Costa Rica, Curridabat, Costa Rica.

12. Moya, R.; Muñoz, F., 2010: Physical and mechanical properties of eight fast-growing plantation species in Costa Rica. Journal of Tropical Forest Science 22(3): 317-328.

13. Panshin, A J.; de Zeeuw, C., 1980: Textbook of wood technology. Ed.4. McGrawHill Book Company, New York.
14. Parsapajouh, D., 1998: Wood Technology. 4th ed. Tehran University, No: 1851, Iran.

15. Shupe, T. F.; Aguilar, R. T.; Vlosky, R. T.; Belisle, M.; Chavez, A., 2005: Wood properties of selected lesserused Honduran wood species. Journal of Tropical Forest Science 17(3): 438-446.

16. Taylor, F. W.; Wooten, T. E., 1973: Wood property variation of Mississippi delta hardwoods. Wood \& Fiber 5(1): 2-13.

17. Zahner, R., 1968: Site quality and wood quality in upland hardwoods: theoretical considerarions of wood density. In: C.T. Youngberg \& C.B. Davey, Tree growth and forest soils: $472-497$.

18. Zhang, S. Y., 1997: Wood specific gravity-mechanical property relationship at species level. Wood Sci Tech 31: 181-191.

19. Zhang, S. Y.; Zhong, Y., 1990: Effect of growth rate on specific gravity of East-Liaoning oak (Quercus liaotungensis) wood. Can. J. For. Res. 21: 255 -260.

20. Zobel, B.; Sprague, J., 1998: Juvenile wood in trees. Springer-Verlag, New York.

21. Zobel, B.; Van Buijtenen, B., 1989: Wood Variation: Its Causes and Control. Springer Verlag, New York.

\section{Corresponding address:}

Professor MAJID KIAEI

Department of Wood and Paper Science and

Technology

Chaloos Branch, Islamic Azad University

Chaloos, Mazandaran, IRAN

e-mail: mjd_kia59@yahoo.com 